\title{
UPAYA MENINGKATKAN HASIL BELAJAR DAN AKTIVITAS SISWA DALAM PEMBELAJARAN BAHASA INDONESIA MELALUI PEMBELAJARAN KOOPERATIF TIPE STAD KELAS X SMA PKP DKI JAKARTA
}

\author{
Dr. Tongato, M. Si \\ Guru SMA PKP Jakarta Islamic School; \\ Alumni Program Doktor Manajemen Pendidikan Univeritas Negeri Jakarta \\ email: tongatomatmowinoto@gmail.com
}

\begin{abstract}
The classroom action research as always been one of the most important learning process issues at school. Due to this importance, a research to improve activities and student learning outcomes needs to be done. This paper is focus on how to improve activities and student learning outcomes through Cooperative Teaching Type A (Divisions of Achievement) STAD Class X SMA PKP DKI Jakarta. This research will be devided into three cycles to analyze classroom action research. In the first cycle, student activity are increased reached the average of 57, the second cycle average 66 and the third cycle average 85. In the first cycle, teacher activity in learning process is also increased reached the average of 75, the second cycle average 82 and the third cycle average 86. In the first cycle, the competence of students are increases by implementing Cooperative Teaching STAD reached the average of 67, the second cycle average 70 and the third cycle average 81. It can be concluded that the application of STAD cooperative teaching can increase the students and teachers activity of learning process and can create the atmosphere of learning more comfortable and fun.
\end{abstract}

Keywords: hasil belajar, aktivitas siswa dan pembelajaran kooperatif

\section{PENDAHULUAN}

Pemberlakuan Kurikulum 2013 membawa perubahan dalam metode dan pendekatan pembelajaran bahasa Indonesia. Pembelajaran dengan pendekatan pada fungsi bahasa, meskipun pada masa sebelumnya sudah dimulai, namun dengan hadirnya Kurikulum 2013 menjadi sesuatu yang lebih dikedepankan. Dengan pendekatan fungsi bahasa ini, pembelajaran bahasa lebih memprioritaskan penguasaan penggunaan bahasa daripada penguasaan struktur (tata bahasa).

Hal tersebut di atas penting mengingat persoalan pembelajaran bahasa Indonesia selama ini belum juga mampu membangun cara berpikir siswa. Sebab, selain berfungsi sebagai sarana komunikasi, bahasa juga sebagai sarana pembentuk pikiran. Dengan penguasaan penggunaan bahasa yang baik, maka akan membimbing siswa dalam berpikir. Pola pikir akan terbentuk manakala siswa menguasai secara baik penggunaan bahasanya.
Agar siswa menguasai bahasa Indonesia dengan baik, Kurikulum 2013 menerapkan pembelajaran berbasis teks sesuai dengan konteks tujuan dan fungsi sosialnya. Pembelajaran bahasa Indonesia berbasis teks menerapkan prinsip-prinsip sebagai berikut: pertama, bahasa hendaknya dipandang sebagai teks, bukan semata-mata kumpulan kata atau kaidah kebahasaan; kedua, penggunaan bahasa merupakan proses pemilihan bentuk-bentuk kebahasaan untuk mengungkapkan makna; ketiga, bahasa bersifat fungsional, yaitu penggunaan bahasa yang tidak pernah dapat dilepaskan dari konteks karena bentuk bahasa yang digunakan itu mencerminkan ide, sikap, nilai dan ideologi penggunanya; dan keempat, bahasa merupakan sarana pembentukan kemampuan berpikir manusia.

Memperhatikan pendekatan pembelajaran bahasa Indonesia yang memprioritaskan penguasaan penggunaan bahasa Indonesia sebagaimana tergambarkan pada deskripsi di atas, maka seharusnya pembelajarannya di 
sekolah merupakan kegiatan yang disenangi, menantang dan bermakna bagi siswa.

Namun dalam kenyataannya, pembelajaran bahasa masih menyisakan pola-pola pendekatan lama. Siswa masih belum terbiasa menggunakan bahasa Indonesia sebagai pola pikir yang terstruktur dan mengalir. Ada ketersendatan dalam penggunaan bahasa Indonesia secara lisan, dan terlebih secara tertulis. Ada kesulitan dalam membangun dan menuangkan ide, konsep dan hasil pengamatan ke dalam bahasa yang runut dan enak dibaca.

Hal ini terjadi karena keterlibatan siswa dalam pembelajaran bahasa masih belum optimal. Ada kekhawatiran salah dalam penggunaan bahasa Indonesia, meskipun sudah dikuasai dan digunakan siswa dalam kehidupan sehari-hari. Ini menjadi tugas guru untuk mendorong dan meningkatkan partisipasi siswa dalam pembelajaran. Guru sudah semestinya meningkatkan kepercayaan diri siswa dalam penggunaan bahasa Indonesia, baik secara lisan maupun tulisan dalam pembelajaran.

Akibat dari keadaan ini, adalah prestasi hasil belajar siswa dalam pembelajaran bahasa Indonesia menjadi memprihatinkan. Agar pembelajaran bahasa Indonesia mencapai tujuan, yakni siswa mahir menguasai dan menggunakan bahasa Indonesia, maka dalam proses pembelajaran yang aktif, kreatif, efektif, inovatif dan menyenangkan menjadi kaharusan penggunaannya dalam berbagai cara. Salah satu cara yang cukup efektif adalah melalui penerapan model pembelajaran kooperatif tipe Student Achievement Divisions (STAD). Oleh karena itu perlu diadakan penelitian tindakan kelas untuk membuktikan bahawa melalui penerapan pembelajaran kooperatif tipe STAD dapat meningkatkan proses dan hasil belajar siswa dalam pembelajaran bahasa Indonesia.

Berdasarkan latar belakang masalah di atas, maka dapat diidentifikasi kondisi pembelajaran sebagai berikut:

1) Pembelajaran bahasa Indonesia masih konvensional,

2) Belum optimalnya partisipasi siswa dalam pembelajaran,

3) Aktivitas siswa dalam pembelajaran sebagian masih memprihatinkan,

4) Rendahnya hasil belajar siswa.
Berdasarkan identifikasi masalah di atas, permasalahan penelitian ini dapat dirumuskan sebagai berikut:

1) Apakah penerapan pembelajaran kooperatif tipe STAD dapat meningkatkan aktivitas siswa dalam pembelajaran mata pelajaran bahasa Indonesia?

2) Apakah penerapan pembelajaran kooperatif tipe STAD dapat meningkatkan hasil belajar siswa mata pelajaran bahasa Indonesia?

Pemecahan masalah yang akan digunakan dalam Penelitian Tindakan Kelasa (PTK) ini, yaitu dengan menerapkan model pembelajaran kooperatif dengan tipe STAD. Dengan model ini diharapkan aktivitas dan hasil belajar siswa dalam pembelajaran bahasa Indonesia meningkat.

Tujuan penelitian ini adalah untuk:

1) Meningkatkan aktivitas siswa dalam pembelajaran

2) Meningkatkan hasil belajar siswa

Manfaat penelitian ini adalah:

1) Proses pembelajaran menjadi lebih partisipatif,

2) Keberanian siswa untuk berbicara/menanggapi materi pelajaran meningkat,

3) Penguasaan siswa terhadap materi pembelajaran meningkat,

4) Hasil belajar siswa meningkat.

\section{KAJIAN LITERATUR DAN PEGEMBANGAN HIPOTESIS}

\section{A. Pembelajaran Kooperatif}

Pembelajaran menurut Dale $\mathrm{H}$ Schunk (2012: 5) merupakan perubahan yang bertahan lama dalam perilaku, atau dalam kapasitas berperilaku dengan cara tertentu, yang dihasilkan dari praktik atau bentuk-bentuk pengalaman lainnya. Kunandar (2007: 265) mendefinisikannya sebagai proses interaksi antara peserta didik dengan lingkungannya sehingga terjadi perubahan perilaku ke arah yang lebih baik. Dan Sukmadinata (2007: 112) mengibaratkan pembelajaran sebagai mata uang yang memiliki dua sisi. Dari sisi guru 
disebut pengajaran dan dari sisi peserta didik disebut belajar. Keduanya tidak bisa dipisahkan yang sering kita sebut sebagai kegiatan belajarmengajar.

Suatu kegiatan dikatakan bentuk pembelajaran menurut Dale H Schunk (2012: 5) bila memenuhi tiga karakteristik berikut. Pertama, melibatkan perubahan. Perubahan di sini dimaksudkan sebagai perubahan yang ada dalam diri pembelajar. Oleh karenanya. seseorang dikatakan telah melakukan pembelajaran bila ada perubahan dalam kapasitas perilakunya, baik yang menyangkut sikap, pengetahuan dan keterampilannya. Kedua, bertahan lama seiring waktu. Ini artinya hasil pembelajaran berupa adanya perubahan pada diri seseorang yang bertahan lama. Perubahan yang hanya sesaat tidak dikatakan sebagai pembelajaran, seperti karena adanya pengaruh obat-obatan ataupun kelelahan. Ketiga, terjadi melalui pengalaman. Hasil perubahan yang bertahan lama dalam diri seseorang yang melakukan kegiatan pembelajaran didapat melalui pengalamannya sendiri. Perubahan yang terjadi pada diri seseorang yang tidak melalui pengalamannya sendiri tidak dapat dikatakan sebagai hasil pembelajaran, seperti karena faktor genetis atau kematangan organ-organ tubuhnya.

Sementara itu pembelajaran kooperatif merupakan pembelajaran yang menekankan kerjasama antarsiswa dalam rangka mencapai tujuan bersama. Slavin dalam Suyanto dan Asep Jihad (2013: 142) mendefinisikan pembelajaran kooperatif sebagai suatu model pembelajaran yang memberikan kesempatan siswa belajar dan bekerja secara kolaboratif dalam kelompok-kelompok kecil dengan struktur heterogen yang terdiri dari 4 - 6 orang.

Pembelajaran kooperatif didefinisikan Sanjaya (2007: 174) sebagai strategi pengajaran yang menekankan kepada proses kerjasama dalam kelompok yang bisa terdiri dari 3 sampai 5 orang peserta didik untuk mempelajari suatu materi akademik yang spesifik sampai tuntas. Agar tujuannya tercapai, setiap anggota kelompok harus bekerjasama, saling membantu. Peserta didik yang memiliki kemampuan cepat dalam belajar, wajib membantu peserta didik yang lama dalam belajar. Hal ini karena penilaian akhir bukan saja ditentukan oleh keberhasilan individu, tetapi yang lebih penting adalah keberhasilan kelompok.

Slavin, Abrani dan Chambers dalam Sanjaya (2007: 174 - 175) menjelaskan bahwa pembelajaran kooperatif dapat dijelaskan dari empat perspektif. Pertama perspektif motivasi, yaitu penghargaan yang diberikan kepada kelompok memungkinkan setiap anggota kelompok akan saling membantu. Kedua perspektif sosial yaitu setiap anggota kelompok akan saling membantu dalam belajar, karena mereka menginginkan semua anggota kelompok meraih keberhasilan. Ketiga, perspektif perkembangan kognitif yaitu adanya interaksi antara anggota kelompok dapat mengembangkan prestasi peserta didik untuk berpikir mengolah berbagai informasi. Keempat, perspektif elaborasi kognitif, yaitu setiap peserta didik akan berusaha untuk memahami dan menimba informasi untuk menambah pengetahuan kognitifnya.

Strategi pembelajaran kooperatif menurut Sanjaya (2007: 175) dapat digunakan manakala guru menekankan pentingnya (1) usaha kolektif disamping usaha individu dalam belajar, (2) keberhasilan belajar seluruh peserta didik, (3) peserta didik belajar dari teman dan dengan bantuan orang lain, (4) mengembangkan kemampuan komunikasi peserta didik, (5) peningkatan motivasi dan partisipasi peserta didik, dan (6) kemampuan peserta didik dalam memecahkan masalah. Dalam hal ini menurut Mulyasa (2007: 53) menekankan akan pentingnya guru bertindak sebagai agen pembelajaran.

Menurut Suyanto dan Asep Jihad (2013: 142), pembelajaran kooperatif memiliki ciriciri:

1) Bertujuan menuntaskan materi yang dipelajari, dengan cara siswa belajar dalam kelompok secara kooperatif;

2) Kelompok yang dibentuk terdiri dari siswa-siswa yang memiliki kemampuan tinggi, sedang, dan rendah;

3) Jika dalam kelas terdapat siswa-siswa yang terdiri dari beberapa ras, suku, 
budaya, jenis kelamin yang berbeda, maka diupayakan agar dalam tiap kelompok terdiri dari ras, suku, budaya, jenis kelamin yang berbeda pula;

4) Penghargaan atas keberhasilan belajar lebih diutamakan pada kerja kelompok daripada perorangan.

Agar pembelajaran kooperatif berjalan dengan efektif, Lundgren dalam Suyanto dan Asep Jihad (2013: 143) menyarankan dalam pembelajaran ditanamkan unsur-unsur dasar belajar kooperatif, yaitu:

1) Siswa harus memiliki persepsi bahwa mereka "tenggelam atau berenang bersama";

2) Siswa memiliki tanggung jawab terhadap siswa dalam kelompoknya, di samping tanggung jawab terhadap diri sendiri dalam mempelajari materi yang dihadapi;

3) Siswa harus berpandangan bahwa mereka memiliki tujuan yang sama;

4) Siswa harus berbagi tugas dan tanggung jawab yang sama besar;

5) Siswa akan diberi suatu evaluasi atau penghargaan, yang lain ikut berpengaruh terhadap evaluasi seluruh kelompok;

6) Siswa berbagi kepemimpinan, sementara mereka memperoleh keterampilan bekerja sama selama belajar;

7) Siswa diminta mempertanggungjawabkan secara individual materi yang dipelajari dalam kelompok kooperatif.

Ada banyak manfaat pembelajaran kooperatif bila diterapkan dengan baik. Menurut Killen dalam Suyanto dan Asep Jihad (2013: 144-145), model pembelajaran kooperatif bermanfaat dalam hal:

1) Mengajarkan siswa untuk mengurangi ketergantungannya pada guru dan lebih percaya diri pada kemampuan diri mereka.

2) Mendorong siswa untuk mengungkapkan ide-ide secara verbal;
3) Membantu siswa untuk belajar bertanggungjawab dan belajar menerima perbedaan;

4) Membantu siswa memperoleh hasil belajar yang baik, meningkatkan hubungan sosial, hubungan positif antarindividu, memperbaiki keterampilan dalam mengatur waktu;

5) Memetik banyak pelajaran dari kerja sama yang dibangun;

6) Siswa akan lebih banyak belajar, menyukai sekolah, menyukai antarsesamanya;

7) Mempertinggi kemampuan siswa untuk menggunakan informasi dan keterangan pelajaran abstrak yang kemudian dapat diubah siswa menjadi suatu keputusan yang riil;

8) Memberikan beberapa kesempatan pada siswa untuk membandingkan jawaban dan mencocokkannya dengan jawaban yang benar.

\section{B. Pembelajaran Kooperatif Tipe STAD}

Pembelajaran kooperatif tipe Student Team Achievement Division (STAD) dikembangkan oleh Robert Slavin dan teman-temannya dari Universitas John Hopkin, Amerika Serikat. Pembelajaran tipe ini dinilai paling sederhana dalam pembelajaran kooperatif.

Langkah-langkah pembelajaran kooperatif tipe STAD menurut Kunandar (2008: 275) sebagai berikut:

1) Para siswa di dalam kelas dibagi menjadi beberapa kelompok dengan anggota $4-5$ siswa. Tiap kelompok memiliki anggota yang beragam, baik dari jenis kelamin, ras, etnik, latar belakang sosial, ekonomi dan budaya serta kemampuan akademik;

2) Guru menyampaikan materi;

3) Guru memberikan tugas kepada kelompok dengan menggunakan lembar kerja, dan kemudian tiap anggota kelompok saling membantu dalam upaya menguasai materi pelajaran dengan tanya jawab atau diskusi;

4) Guru memberikan pertanyaan atau kuis kepada seluruh siswa. Siswa tidak 
boleh saling membantu ketika sedang menjawab pertanyaan atau kuis;

5) Setiap akhir pelajaran, guru memberikan evaluasi untuk mengukur penguasaan materi pelajaran para siswa;

6) Tiap siswa dan tiap kelompok diberi skor atas penguasaannya terhadap materi pelajaran. Guru memberikan pengharagaan kepada siswa atau kelompok yang memperoleh skor tertinggi;

7) Guru membuat kesimpulan. Caranya, dapat dilakukan dengan memberi kesempatan kepada siswa untuk membuat kesimpulan.

C. Hakikat Aktivitas Siswa dan Hasil Belajar

\section{Hakikat Aktivitas Siswa}

Gie dalam Khoerul (2015) mendefinisikan aktivitas siswa dalam belajar sebagai segenap rangkaian kegiatan atau aktivitas secara sadar yang dilakukan oleh seseorang yang mengakibatkan perubahan dalam dirinya, berupa perubahan pengetahuan atau kemahiran yang sifatnya tergantung pada sedikit banyaknya perubahan. Sedangkan menurut Sardiman dalam Khoerul (2015), aktivitas dalam proses belajar mengajar adalah rangkaian kegiatan yang meliputi keaktifan siswa dalam mengikuti pelajaran, bertanya hal yang belum jelas, mencatat, mendengar, berpikir, membaca dan segala kegiatan yang dilakukan yang dapat menunjang prestasi belajar.

Sementara itu, Dimyati dalam Khoerul (2015) menyatakan bahwa keaktifan siswa dalam pembelajaran memiliki bentuk yang beraneka ragam, dari kegiatan fisik yang mudah diamati sampai kegiatan psikis yang sulit diamati. Kegiatan fisik yang dapat diamati diantaranya adalah kegiatan dalam bentuk membaca, mendengarkan, menulis, meragakan, dan mengukur. Sedangkan contoh kegiatan psikis diantaranya adalah seperti mengingat kembali isi materi pelajaran pada pertemuan sebelumnya, menggunakan khasanah pengetahuan yang dimiliki untuk memecahkan masalah, menyimpulkan hasil eksperimen, membandingkan satu konsep dengan konsep yang lain, dan lainnya.

Menurut Kunandar (2008: 277) aktivitas siswa dalam pembelajaran adalah keterlibatan siswa dalam bentuk sikap, pikiran, perhatian, dan aktivitas dalam kegiatan pembelajaran guna menunjang keberhasilan proses belajar dan mengajar dan memperoleh manfaat dari kegiatan tersebut.

Indikator aktivitas siswa menurut Kunandar (2008: 276) dapat dilihat dari: pertama, mayoritas siswa beraktivitas dalam pembelajaran; kedua, aktivitas pembelajaran didominasi oleh kegiatan siswa; ketiga, mayoritas siswa mampu mengerjakan tugas yang diberikan guru.

Dalam PTK ini, yang dimaksud dengan aktivitas siswa tampak dalam hal-hal berikut:

a. Siswa senang bertanya;

b. Siswa senang mengerjakan tugas yang diberikan;

c. Siswa berlomba untuk menjawab pertanyaan atau kuis dari guru;

d. Siswa senang berbagi pemahaman tentang materi pelajaran yang sudah diketahui kepada sesama teman;

e. Siswa mengumpulkan tugas dengan segera.

\section{Hakikat Hasil Belajar}

Belajar merupakan aktivitas mental/psikis yang berlangsung dalam dalam interaksi aktif dengan lingkungan yang menghasilkan sejumlah perubahan yang bersifat relatif tetap konstan dan berbekas dalam pengetahuanpemahaman, keterampilan dan nilai-sikap (Winkel, 2005: 59). Dalam definisi ini terungkap adanya perubahan sebagai hasil belajar. Namun demikian, tidak semua perubahan merupakan hasil belajar, semisal perubahan karena kelelahan fisik, penggunaan obat, akibat pertumbuhan fisik dan akibat penyakit parah atau trauma fisik.

Hampir senada dengan Winkel, Kimble dalam Hergenhahn dan Olson (2008: 2 - 3) mendefinisikan belajar sebagai perubahan yang relatif permanen di dalam potensi behavioral yang terjadi sebagai akibat dari praktik yang 
diperkuat. Dalam kaitan ini, hasil belajar diterjemahkan ke dalam perilaku atau tindakan yang dapat diamati. Indikatornya, peserta didik yang telah mengikuti proses belajar akan mampu melakukan sesuatu yang tidak bisa mereka lakukan sebelum mereka mengikuti proses pembelajaran.

Menurut Syah (2008: 118 - 121) perwujudan perilaku belajar sebagai bentuk hasil belajar akan tampak dalam perubahanperubahan antara lain dalam hal kebiasaan, keterampilan, berpikir, dan bersikap peserta didik. Tentu perubahan-perubahan ini dapat diukur melalui serangkain evaluasi yang dapat dilakukan guru.

Sementara itu, Sudjana dalam Kunandar (2008: 276) mendefinisikan hasil belajar sebagai suatu akibat dari proses belajar dengan menggunakan alat pengukuran, yaitu berupa tes yang disusun secara terencana, baik tes lisan, tulis, maupun perbuatan.

Hasil belajar merupakan bagian terpenting dalam pembelajaran. Sudjana dalam Yulia (2015) menyatakan bahwa hasil belajar siswa adalah perubahan tingkah laku sebagai hasil belajar dalam pengertian yang lebih luas mencakup bidang kognitif, afektif, dan psikomotorik. Sedangkan, Dimyati dan Mudjiono dalam Yulia (2015) juga menyebutkan hasil belajar sebagai hasil dari suatu interaksi tindak belajar dan tindak mengajar.

Hasil belajar siswa merujuk pada hasil nilai ulangan harian (formatif), nilai ulangan tengah semester (subsumatif) dan nilai ulangan semester (subsumatif). Dalam PTK ini, yang dimaksud dengan hasil belajar siswa adalah hasil nilai ulangan harian yang diperoleh siswa dalam mata pelajaran bahasa Indonesia. Ulangan harian dilaksanakan setiap akhir proses pembelajaran satuan bahasan atau kompetensi. Ulangan harian terdiri dari seperangkat soal yang harus dijawab siswa, dan tugas-tugas struktur yang berkaitan dengan kompetensi yang telah dipelajari. adalah:

Hipotesis tindakan dalam penelitian ini
1) Penerapan pembelajaran kooperatif tipe STAD dapat meningkatkan aktivitas siswa dalam pembelajaran bahasa Indonesia,

2) Penerapan pembelajaran kooperatif tipe STAD dapat meningkatkan hasil belajar siswa.

\section{METODE PENELITIAN}

A. Setting Penelitian

Seting dalam penelitian ini meliputi: tempat, waktu, dan siklus penelitian, sebagai berikut:

1) Tempat

PTK ini dilaksanakan di SMA PKP Jakarta Islamic School, Jakarta Timur untuk mata pelajaran Bahasa Indonesia.

\section{2) Waktu}

PTK dilaksanakan pada tahun pelajaran 2014/2015, yaitu Februari sampai dengan Maret 2015.

\section{3) Siklus}

PTK ini dilaksanakan dalam 3 siklus untuk melihat aktivitas belajar siswa dan hasil belajar siswa dalam pembelajaran Bahasa Indonesia dengan menggunakan pembelajaran kooperatif tipe STAD.

\section{B. Persiapan Penelitian}

Sebelum melaksanakan PTK, penulis telah mempersiapkan rencana pelaksanaan pembelajaran (RPP) yang memuat Kompetensi Inti (KI) dan Kompetensi Dasar (KD) sebagai berikut:

\section{Kompetensi Inti}

1. Menghayati dan mengamalkan ajaran agama yang dianutnya

2. Menghayati dan mengamalkan perilaku jujur, disiplin, tanggung jawab, peduli (gotong royong, kerja sama, toleran, damai), santun, responsif dan pro-aktif dan menunjukkan sikap sebagai bagian dari solusi atas berbagai permasalahan 
dalam berinteraksi secara efektif dengan lingkungan sosial dan alam serta dalam menempatkan diri sebagai cerminan bangsa dalam pergaulan dunia

3. Memahami, menerapkan, menganalisis pengetahuan faktual, konseptual, prosedural berdasarkan rasa ingin tahunya tentang ilmu pengetahuan, teknologi, seni, budaya, dan humaniora dengan wawasan kemanusiaan, kebangsaan, kenegaraan, dan peradaban terkait fenomena dan kejadian, serta menerapkan pengetahuan prosedural pada bidang kajian yang spesifik sesuai dengan bakat dan minatnya untuk memecahkan masalah

4. Mengolah, menalar, dan menyaji dalam ranah konkret dan ranah abstrak terkait dengan pengembangan dari yang dipelajarinya di sekolah secara mandiri, dan mampu menggunakan metode sesuai kaidah keilmuan.

\section{Kompetensi Dasar}

1.1. Mensyukuri anugerah Tuhan akan keberadaan bahasa Indonesia dan menggunakannya sesuai dengan kaidah dan konteks untuk mempersatukan bangsa

1.2. Mensyukuri anugerah Tuhan akan keberadaan bahasa Indonesia dan menggunakannya sebagai sarana komunikasi dalam memahami, menerapkan, dan menganalisis informasi lisan dan tulis melalui teks anekdot, laporan hasil observasi, prosedur kompleks, dan negosiasi

1.3. Mensyukuri anugerah Tuhan akan keberadaan bahasa Indonesia dan menggunakannya sebagai sarana komunikasi dalam mengolah, menalar, dan menyajikan informasi lisan dan tulis melalui teks anekdot, laporan hasil observasi, prosedur kompleks, eksposisi, dan negosiasi

2.4. Menunjukkan perilaku jujur, disiplin, peduli, dan santun dalam menggunakan bahasa Indonesia untuk bernegosiasi merundingkan masalah perburuhan, perdagangan, dan kewirausahaan
3.1. Memahami struktur dan kaidah teks anekdot, laporan hasil observasi, prosedur kompleks, eksposisi, dan negosiasi, baik melalui lisan maupun tulisan

3.2. Membandingkan teks anekdot, laporan hasil observasi, prosedur kompleks, eksposisi, dan negosiasi, baik melalui lisan maupun tulisan

3.3. Menganalisis teks anekdot, laporan hasil observasi, prosedur kompleks, eksposisi, dan negosiasi, baik melalui lisan maupun tulisan

3.4. Mengevaluasi teks anekdot, laporan hasil observasi, prosedur kompleks, eksposisi, dan negosiasi berdasarkan kaidahkaidah teks, baik melalui lisan maupun tulisan

4.1. Menginterpretasi makna teks anekdot, laporan hasil observasi, prosedur kompleks, eksposisi, dan negosiasi, baik secara lisan maupun tulisan

4.2. Memproduksi teks anekdot, laporan hasil observasi, prosedur kompleks, eksposisi, dan negosiasi yang koheren sesuai dengan karakteristik teks yang akan dibuat, baik secara lisan maupun tulisan

4.3. Menyunting teks anekdot, laporan hasil observasi, prosedur kompleks, eksposisi, dan negosiasi sesuai dengan struktur dan kaidah teks, baik secara lisan maupun tulisan

4.4. Mengabstraksi teks anekdot, laporan hasil observasi, prosedur kompleks, eksposisi, dan negosiasi, baik secara lisan maupun tulisan

4.5. Mengonversi teks anekdot, laporan hasil observasi, prosedur kompleks, eksposisi, dan negosiasi ke dalam bentuk yang lain sesuai dengan struktur dan kaidah teks, baik secara lisan maupun tulisan

Selain itu, peneliti juga membuat perangkat pembelajaran berupa lembar kerja siswa, lembar pengamatan diskusi dan lembar evaluasi. 


\section{Subjek Penelitian}

PTK ini menggunakan subjek siswa kelas X MIA 2 tahun pelajaran 2014/2015 dengan jumlah siswa 31 orang, terdiri dari 21 siswa laki-laki, dan 10 siswa perempuan.

\section{Sumber Data}

Sumber data PTK ini meliputi siswa dan guru/teman sejawat sebagai kolaborator. Siswa sebagai sumber data tentang hasil belajar dan aktivitas siswa dalam proses pembelajaran.

\section{E. Teknik dan Alat Pengumpul Data}

Teknik dan alat pengumpulan data dalam penelitian ini menggunakan tes, observasi, dan diskusi. Tes yang berupa butir soal digunakan untuk mendapatkan data tentang hasil belajar; observasi yang berupa lembar observasi untuk memperoleh data aktivitas siswa dalam pembelajaran; dan diskusi untuk refleksi hasil siklus penelitian berdasar lembar pengamatan.

\section{F. Analisis Data}

Data yang terkumpul dalam penelitian dianalisis secara deskriptif, kemudian dipersentasekan untuk melihat kecenderungan yang terjadi dalam pembelajaran yang meliputi:

\section{Aktivitas siswa}

Aktivitas siswa yang dimaksud adalah aktivitas siswa dalam pembelajaran bahasa Indonesia dengan menggunakan pembelajaran kooperatif tipe STAD yang terekam dalam lembar observasi. Hasil isian lembar observasi kemudian dikelompokkan dalam klasifikasi tinggi, sedang dan rendah.

\section{Hasil belajar}

Hasil belajar siswa yang diperoleh berdasar butir soal yang dikerjakan siswa diklasifikasi dalam tinggi, sedang dan rendah.

\section{G. Prosedur Penelitian}

\section{Siklus 1}

Siklus 1 dalam PTK ini terdiri dari perencanaan, pelaksanaan, pengamatan dan refleksi sebagai berikut:

\section{Perencanaan}

Kegiatan perencaan meliputi:

a. Analisis kurikulum untuk mengetahui kompetensi dasar yang akan digunakan dalam pembelajaran kooperatif tipe STAD;

b. Membuat RPP

c. Membuat lembar kerja siswa

d. Membuat lembar observasi

e. Membuat instrumen tes

2. Pelaksanaan

Kegiatan pelaksanaan meliputi:

a. Membagi siswa dalam 6 kelompok

b. Menyajikan materi pelajaran

c. Memberikan materi diskusi

d. Siswa berdikusi kelompok, guru mengarahkannya

e. Salah satu kelompok mempresentasikan hasil diskusi kelompok pada diskusi kelas;

f. Guru memberikan pertanyaan atau kuis

g. Siswa diberi kesempatan menanggapi hasil presentasi;

h. Guru melakukan pengamatan diskusi kelompok dan kelas;

i. Guru memberikan penguatan dan kesimpulan

3. Pengamatan
a. Partisipasi siswa;
b. Situasi kegiatan pembelajaran;
c. Kemampuan siswa dalam diskusi.
d. Refleksi

PTK dikatakan berhasil apabila:

a. Sebanyak $70 \%$ atau lebih siswa berani bertanya dalam diskusi;

b. Sebanyak $70 \%$ atau lebih siswa berani mengemukaan pendapat dalam diskusi; 
c. Sebanyak $75 \%$ anggota kelompok aktif dalam mengerjakan tugas kelompoknya;

d. Penyelesaian tugas kelompok tepat waktu.

Siklus 2

Sama dengan siklus I, siklus II juga mencakup kegiatan perencanaan, pelaksanaan, pengamatan dan refleksi.

\section{Perencanaan}

Peneliti membuat rencana pembelajaran berdasarkan hasil refleksi siklus 1 .

\section{Pelaksanaan}

Guru dan siswa melakukan pembelajaran kooperatif dengan tipe STAD berdasarkan RPP hasil refleksi pada siklus 1 .

\section{Pengamatan}

Peneliti dan kolabolator melakukan pengamatan terhadap siswa dalam pembelajaran berdasarkan hasil refleksi siklus 1.

\section{Refleksi}

Peneliti melakukan refleksi terhadap pelaksanaan siklus pertama dan membuat kesimpulan atas pelaksanaan pembelajaran.

Siklus 3

Sama dengan siklus 1, siklus 2 juga mencakup kegiatan perencanaan, pelaksanaan, pengamatan dan refleksi.

\section{Perencanaan}

Peneliti dengan masukan kolaborator membuat rencana pembelajaran berdasarkan hasil refleksi siklus 2 .

\section{Pelaksanaan}

Guru dan siswa melakukan pembelajaran kooperatif dengan tipe STAD berdasarkan RPP hasil refleksi pada siklus 2 .

\section{Pengamatan}

Peneliti dan kolabolator melakukan pengamatan terhadap siswa dalam pembelajaran berdasarkan hasil refleksi siklus 2.

\section{Refleksi}

Peneliti melakukan refleksi terhadap pelaksanaan siklus kedua dan membuat kesimpulan atas pelaksanaan pembelajaran. ${ }^{* * *}$

\section{HASIL DAN PEMBAHASAN}

Hasil dan pembahasan PTK diuraikan dalam tiga siklus pembelajaran di kelas dengan paparan sebagai berikut:

\section{A. Siklus Pertama (satu pertemuan)}

Siklus pertama meliputi empat siklus, yakni perencanaan, pelaksanaan, observasi, refleksi dan pembuatan rencana pembelajaran berikutnya sebagai tindak lanjut hasil refleksi. Berikut disampaikan hasil dan pembahasannya:

1. Perencanaan

a. Peneliti melakukan analisis kurikulum untuk menentukan kompetensi inti dan standar kompetensi yang akan dipalajari siswa dengan menggunakan pembelajaran kooperatif tipe STAD,

b. Membuat rencana pembelajaran kooperatif tipe STAD,

c. Membuat lembar kerja siswa,

d. Membuat instrumen yang digunakan dalam pembelajaran,

e. Menyusun alat evaluasi pembelajaran.

2. Pelaksanaan

Pada awal siklus pertama pelaksanaan belum sesuai dengan rencana. Hal ini dikarenakan:

a. Sebagian siswa belum terbiasa dengan pembelajarn kooperatif,

b. Sebagian kelompok belum memahami langkah-langkah pembelajaran koopertaif tipe STAD secara utuh.

Untuk mengatasi hal tersebut, maka guru memberikan informasi tentang manfaat 
pembelajaran kooperatif dan pentingnya kersajama dalam kelompok. Selain itu, guru juga membimbing kelompok yang belum memahami langkah-langkah pembelajaran kooperatif tipe STAD.

Berdasarkan pengamatan peneliti, setelah pelaksanaan pembelajaran siklus pertama dapat disimpulkan:

a. Siswa sudah mulai dapat beradaptasi dalam pembelajaran kooperatif,

b. Siswa mulai memahami pentingnya pembelajaran kooperatif tipe STAD,

c. Siswa memahami bahawa ada langkahlangkah pembelajaran koopertaif tipe STAD.

\section{Observasi}

a. Hasil observasi aktivitas siswa dalam pembelajaran koopertaif tipe STAD selama siklus pertama dapat dilihat sebagai berikut:

\section{Tabel 1}

Perolehan Skor Aktivitas siswa dalam Pembelajaran Siklus 1

\begin{tabular}{|l|l|l|l|l|l|}
\hline No. & Kelompok & $\begin{array}{l}\text { Skor } \\
\text { Rerata } \\
\text { Perolehan }\end{array}$ & $\begin{array}{l}\text { Skor } \\
\text { Ideal }\end{array}$ & Persentase & Keterangan \\
\hline 1. & Bung Karno & 6,6 & 16 & 42 & Terendah \\
\hline 2. & Bung Hatta & 9,6 & 16 & 60 & \\
\hline 3. & Cut Nyak Dien & 10,4 & 16 & 65 & Tertinggi \\
\hline 4. & Jend Soedirman & 9,2 & 16 & 57 & \\
\hline 5. & Pattimura & 9,8 & 16 & 61 & \\
\hline & Rerata & 9,1 & 16 & 57 & \\
\hline
\end{tabular}

Grafik 1
Perolehan Skor Aktivitas siswa dalam Pembelajaran Siklus 1

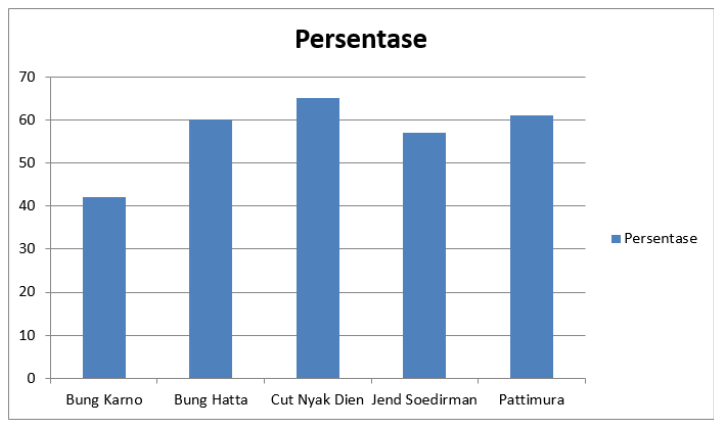

b. Hasil observasi siklus 1, aktivitas guru dalam pembelajaran kurang optimal dengan peroleham skor 33 atau $75 \%$ sedangkan skor idealnya adalah 44 . Hal ini terjadi karena kurang memberikan arahan/penjelasan dalam pembelajaran kepada siswa tentang bagaimana pembelajaran kooperatif.

c. Hasil evaluasi siklus 1, penguasaan siswa terhadap materi pelajaran pun tergolong rendah. Dari skor idela 100, skor perolehan rerata siswa hanya mencapai 67 atau $67 \%$.

4. Refleksi dan rencana pembelajaran berikutnya

Catatan hasil siklus 1 sebagai berikut:

a. Siswa belum terbiasa dengan pembelajaran kooperatif tipe STAD. Mereka belum merasa nyaman dalam pembelejaran. Hal in terbukti dengan perolehan hasil observasi aktivitas siswa yang hanya mencapai $57 \%$.

b. Guru belum familiar dengan pembelajaran kooperatif tipe STAD. Hal terbukti dari hasil observasi terhadap aktivitas guru dalam pembelajaran yang hanya memperoleh $75 \%$.

c. Hasil evaluasi belajar siklus pertama hanya mencapai rerata 67.

d. Masih ada anggota kelompok yang belum terlibat secara aktif dalam kegiatan belajar kooperatif. Hal ini karena mereka belum memahami dengan baik cara pembelajaran yang diterapkan. 
Untuk memperbaiki keadaan tersebut di atas dan juga mempertahankan hal-hal yang sudah baik, sebagaiknya guru melakukan halhal berikut:

a. Terus memberikan motivasi pentingnya pembelajaran kooperatif.

b. Menjelaskan kembali pemahaman pembelajaran kooperatif peserta peran yang harus diambil setiap siswa.

c. Terhadap perkembangan yang dicapai siswa, guru harus selalu memberikan penghargaan atau pengakuan.

B. Siklus Kedua (satu pertemuan)

Siklus 2 terdiri dari perencanaan, pelaksanaan, observasi dan refleksi yang diikuti perencanaan kembali untuk pembelajaran yang akan datang.

\section{Perencanaan}

Perencanan siklus kedua berdasarkan perencanaan ulang siklus pertama dilakukan dengan kegiatan sebagai berikut:

a. Memberikan motivasi kembali agar lebih aktif aktif dalam pembelajaran

b. Memberikan pemahaman secara lebih intensif akan peran yang harus diambil peserta pembelajaran

c. Memberikan pengakuan atau penghargaan terhadap pencapain belajar siswa.

\section{Pelaksanaan}

Pada siklus kedua ini pelaksanaan pembelajaran sudah mulai lancar dikarenakan:

a. Siswa sudah terbiasa dengan pembelajarn kooperatif,

b. Anggota kelompok sudah memahami langkah-langkah pembelajaran koopertaif tipe STAD secara utuh.

c. Kerjasama anggota dalam kelompok sudah muali mengalir.

d. Guru secara lebih intensif membimbing kelompok yang untuk lebih intensif memahami langkahlangkah pembelajaran kooperatif tiepe STAD. e. Susasana pembelajaran sudah berjalan lebih menyenangkan.

\section{Observasi}

a. Hasil observasi aktivitas siswa tergambar dalam tabel berikut:

Tabel 2

Perolehan Skor Aktivitas siswa dalam Pembelajaran Siklus 2

\begin{tabular}{|l|l|l|l|l|l|}
\hline No. & Kelompok & $\begin{array}{l}\text { Skor } \\
\text { Rerata } \\
\text { Perolehan }\end{array}$ & $\begin{array}{l}\text { Skor } \\
\text { Ideal }\end{array}$ & Persentase & Keterangan \\
\hline 1. & Bung Karno & 10,5 & 16 & 66 & \\
\hline 2. & Bung Hatta & 10 & 16 & 63 & Terendah \\
\hline 3. & Cut Nyak Dien & 11,6 & 16 & 73 & Tertinggi \\
\hline 4. & Jend Soedirman & 10,4 & 16 & 65 & \\
\hline 5. & Pattimura & 10,4 & 16 & 65 & \\
\hline & Rerata & 11 & 16 & 66 & \\
\hline
\end{tabular}

Grafik 2

Perolehan Skor Aktivitas siswa dalam Pembelajaran Siklus 2

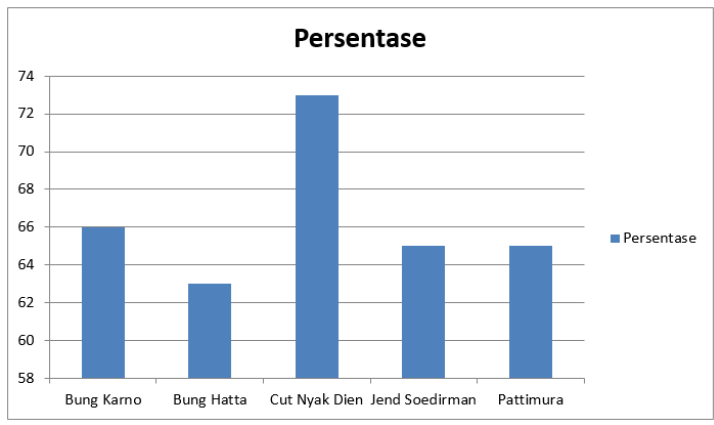

b. Hasil observasi siklus 2, aktivitas guru dalam pembelajaran sudah optimal dengan perolehan skor 36 atau $82 \%$, meskipun belum seidealnya yang diharapkan yakni 44. Arahan/penjelasan guru dalam pembelajaran kepada siswa tentang bagaimana pembelajaran kooperatif sudah mulai mendapatkan hasil yang optimal.

c. Hasil evaluasi siklus 2, penguasaan siswa terhadap materi pelajaran pun tergolong sedang. Dari skor idela 100, skor perolehan rerata siswa hanya mencapai 70 atau $70 \%$. 
4. Refleksi dan perencanaan ulang

Catatan hasil siklus 2 sebagai berikut:

a. Siswa sudah mulai terbiasa dengan pembelajaran kooperatif tipe STAD. Mereka mulai merasa nyaman dalam pembelajaran. Hal ini terbukti dengan perolehan hasil observasi aktivitas siswa yang sudah mencapai $66 \%$. Meskipun demikian, peningkatan harus selalu diupayakan.

b. Guru sudah mulai familiar dengan pembelajaran kooperatif tipe STAD. Hal terbukti dari hasil observasi terhadap aktivitas guru dalam pembelajaran yang sudah memperoleh $81 \%$.

c. Hasil evaluasi belajar siklus kedua sudah mencapai rerata 70. Meskipun demikian, pencapaian rerata ini masih harus diupayakan. Siswa yang belum mendapat nilai optimal harus mendapatkan perhatian lebih ekstra.

d. Meskipun masih ada anggota kelompok yang belum terlibat secara aktif dalam kegiatan belajar kooperatif, namun hal ini jumlahnya tinggal satu dua orang siswa. Hal ini karena mereka sudah memahami dengan baik cara pembelajaran yang diterapkan dan peran masing-masing. Siswa yang belum terlibat secara aktif dalam kelompok, harus diberi motivasi tentang perannya yang harus ditingkatkan.

\section{Siklus Ketiga (satu pertemuan)}

Seperti siklus 3 terdiri dari perencanaan, pelaksanaan, observasi dan evaluasi serta refleksi.

\section{Perencanaan}

Perencanan siklus kedua berdasarkan perencanaan ulang siklus kedua dilakukan dengan kegiatan sebagai berikut:

a. Tetap memberikan motivasi agar lebih aktif dalam pembelajaran

b. Lebih intesif dalam memberikan pemahaman terhadap peran yang harus diambil setiap peserta dalam pembelajaran

c. Memberikan pengakuan atau penghargaan terhadap pencapain belajar siswa.

2. Pelaksanaan

Pada siklus kedua ini pelaksanaan pembelajaran sudah mulai lancar dikarenakan:

a. Siswa sudah termotivasi dan lebih familiar dengan pembelajaran kooperatif,

b. Setiap anggota kelompok sudah memahami langkah-langkah pembelajaran koopertaif tipe STAD secara utuh sehingga suasana pembelajaran berjalan dengan menyenangkan.

c. Kerjasama anggota dalam kelompok sudah mengalir sehingga kesulitan yang muncul segera dapat terpecahkan.

d. Guru merasa enjoy dalam melaksanakan lagkah-langkah pembelajaran kooperatif tipe STAD.

e. Susasana pembelajaran sudah berjalan efektif dan menyenangkan.

3. Observasi

a. Hasil observasi aktivitas siswa tergambar dalam tabel berikut:

Tabel 3

Perolehan Skor Aktivitas siswa dalam Pembelajaran Siklus 3

\begin{tabular}{|l|l|l|l|l|l|}
\hline No. & Kelompok & $\begin{array}{l}\text { Skor } \\
\text { Rerata } \\
\text { Perolehan }\end{array}$ & $\begin{array}{l}\text { Skor } \\
\text { Ideal }\end{array}$ & Persentase & Keterangan \\
\hline 1. & Bung Karno & 13 & 16 & 81 & Terendah \\
\hline 2. & Bung Hatta & 14 & 16 & 87 & \\
\hline 3. & Cut Nyak Dien & 13,2 & 16 & 82 & \\
\hline 4. & Jend Soedirman & 13,6 & 16 & 85 & \\
\hline 5. & Pattimura & 14,6 & 16 & 91 & Tertinggi \\
\hline & Rerata & 13,7 & 16 & 85 & \\
\hline
\end{tabular}

Grafik 3

Perolehan Skor Aktivitas siswa dalam Pembelajaran Siklus 3 


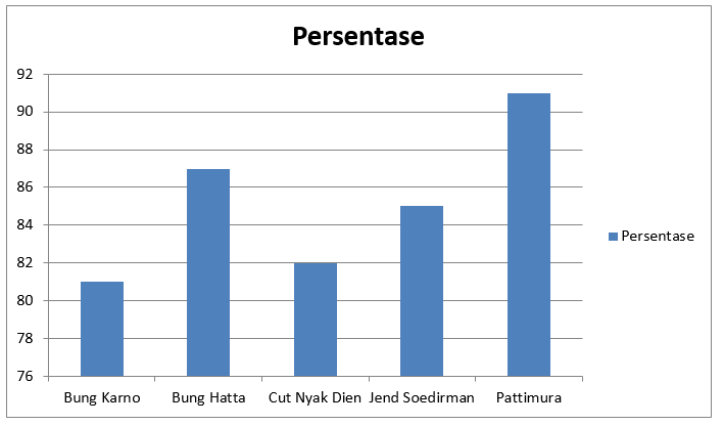

b. Hasil observasi siklus 3, aktivitas guru dalam pembelajaran sudah optimal dengan perolehan skor 38 atau $86 \%$. Hal menunjukkan adanya peningkatan yang sangat signifikan.

c. Hasil evaluasi siklus 3, penguasaan siswa terhadap materi pelajaran mencapai 81. Perolehan ini tergolong tinggi dalam penguasan kompetensi yang dipelajari.

\section{Refleksi}

Catatan hasil siklus 3 sebagai berikut:

a. Siswa sudah terbiasa dengan pembelajaran kooperatif tipe STAD. Pembelajaran berjalan dengan nyaman dan menyenangkan. Hal ini terbukti dengan perolehan hasil observasi aktivitas siswa yang mencapai rerata 85 $\%$ yang sebelumnya hanya mencapai $66 \%$.

b. Guru sudah sangat familiar dengan pembelajaran kooperatif tipe STAD. Hal ini terbukti dari hasil observasi terhadap aktivitas guru dalam pembelajaran yang pada siklus kedua mencapai $81 \%$, pada siklus ketiga sudah memperoleh $86 \%$.

c. Hasil evaluasi belajar siklus ketiga sudah mencapai rerata 81 , meningkat dari sebelumnya yang hanya memperoleh 70. Meskipun demikian, pencapaian rerata ini tetap harus diupayakan.

\section{KESIMPULAN}

Berdasarkan hasil penelitian tindakan kelas di atas dapat disimpulkan sebagai berikut:

a. Penerapan pembelajaran kooperatif tipe STAD terbukti dapat meningkatkan aktivitas proses pembelajaran.

b. Aktivitas siswa dari hasil observasi tercatat meningkat. Pada siklus pertama mencapai rerata 57, siklus kedua rerata 66 dan siklus ketiga mencapai rerata 85 .

c. Aktivitas guru dalam pembelajaran juga mengalami peningkatan. Pada siklus pertama rerata 75 , siklus kedua 82 dan siklus ketiga mencapaiu rerata 86.

d. Dengan pembelajaran kooperatif tipe STAD, penguasaan siswa terhadap kompetensi meningkat. Hal ini terbukti dari hasil evaluasi siklus pertama memperoleh rerata 67 , siklus kedua 70 dan siklus ketiga mencapai rerata 81 .

e. Melalui penerapan pembelajaran kooperatif tipe STAD, suasana pembelajaran menjadi nyaman dan menyenangkan.

Saran

Adanya hasil yang positif dalam penerapan pembelajaran kooperatif tipe STAD pada pembelajaran bahasa Indonesia, maka kami sarankan hal-hal sebagai berikut:

a. Guru hendaknya menggunakan pembelajaran kooperatif tipe STAD dalam kegiatan pembelajaran sebagai alternatif, karena hal tersebut dapat meningkatkan aktivitas dan hasil belajr siswa.

b. Mengingat manfaat yang diperoleh dalam penerapan pembelajaran kooperatif tipe STAD, maka diharapkan dapat pula dilakukan secara berkelanjutan, baik dalam mata pelajaran bahasa Indonesia maupun mata pelajaran lainnya. 
Nidhomul Haq Vol 2 No: 3 November 2017 ISSN 2503-1481

\section{REFERENSI}

Hergenhahn, B.R. dan Matthew H. Olson. 2008. Teori Belajar. Jakarta: Kencana.

Khoerul, Eko. 2015. Konsep Aktivitas. (diakses, 29 September 2015).

Kunandar, 2007. Guru Profesional. Jakarta: Rajawali Pers.

Kunandar, 2008. Langkah Mudah Penelitian Tindakan Kelas, Jakarta: Rajawali Pers.

Mulyasa, E. 2007. Standar Kompetensi dan Sertifikasi Guru. Bandung: Rosdakarya.

Sanjaya, Wina. 2007. "Pengajaran," dalam Ilmu dan Aplikasi Pendidikan. Bandung: Tim Pengembangan Ilmu Pendidikan FIP-UPI.

Schunk, Dale H. 2012. Teori-teori Pembelajaran: Perspektif Pendidikan, Yogyakarta: Pustaka Pelajar.

Sukmadinata, Nana Syaodih. 2007. "Kurikulum dan Pembelajaran," dalam Ilmu dan Aplikasi Pendidikan. Bandung: Tim Pengembangan Ilmu Pendidikan FIP-UPI.

Suyanto dan Asep Jihad. 2013, Menjadi Guru Profesional, Strategi Meningkatkan Kualifikasi dan Kualitas guru di Era Global, Jakarta: Esensi Erlangga group.

Syah, Muhibbin. 2008. Psikologi Pendidikan dengan Pendekatan Baru. Bandung: Rosdakarya.

Winkel, W.S., 2005. Psikologi Pengajaran. Yogyakarta: Media Abadi.

Yulia. 2015. eprints.uny.ac.id/9829/2/bab2, (diakses, 29 September 2015). 